\title{
Expression of aryl hydrocarbon receptor and ATG16L1 protein in experimental oxazolone-induced colitis in rats
}

\author{
Zaporozhye State Medical University; e-mail: gerya2009@yandex.ru
}

\begin{abstract}
We studied the expression of AhR and ATG16L1 protein in experimental oxazolone-induced colitis in rats and anti-inflammatory action of recombinant antagonist of IL-1 receptors (ARIL-1) and simvastatin. The immunopositive cells were determined using an indirect immunofluorescence technique with using a monoclonal rat antibody. It has been established that development of colitis was accompanied by an increase of total number of ATG16L1+-lymphocytes (by $30 \%, P<0.05$ ) in lymphoid structures of the colon. However, the amount of AhR -lymphocytes has not changed. At the same time has increased the concentration of ATG16L1 protein (by 4-11\%, $P<0.05$ ) in immunopositive cells. Administration of simvastatin and ARIL-1 during the development of experimental pathology was accompanied by decrease of total number of AhR $R^{+}$ (by 24-38\%, $P<0.05$ ) and ATG16L1+-lymphocytes (by 43\% - 2 fold, $P<0.05$ ) in the colon.

Key words: colitis; recombinant antagonist of receptors of interleukin-1 (ARIL-1); simvastatin; aryl hydrocarbon receptor; autophagy related 16-like 1 protein.
\end{abstract}

\section{INTRODUCTION}

Ulcerative colitis (UC) and Crohn's disease (CD) are the main clinical phenotypes of inflammatory bowel disease (IBD). Both forms of IBD can increase the incidence of gastrointestinal and colon cancers, and both ones affect individuals throughout life. Although the etiology and pathogenesis of UC and CD has not been fully revealed yet, it is widely accepted that both are complex and multifactorial [1]. The aryl hydrocarbon receptor (AhR), a transcription factor activated by a large number of environmental agents, modulates the activity of immune and nonimmune cells in the gut, and may represent an important link between the environment and the immune perturbations which underlie the pathogenesis of IBD. Recent findings in diverse murine models of colitis have helped to reveal the importance of AhR dysfunction mechanisms in IBD pathogenesis [2]. Although AhR seems to be a crucial cofactor in regulation of both homeostasis and inflammation, its role in the gut autoimmune pathology is poorly described. Conclusion (C) A.S. Zherebiatiev, A.M. Kamyshny from the data obtained from either the ligandactivated AhR cell lineages or AhR null mice clearly states the physiological importance of this receptor in cell growth [3], cell apoptosis [4], and endoplasmic reticulum stress (ER) response [5]. Apoptosis and autophagy are two evolutionarily conserved processes that maintain homeostasis during stress. Although the two pathways utilize fundamentally distinct machinery, apoptosis and autophagy are highly interconnected and share many key regulators. The crosstalk between apoptosis and autophagy is complex, as autophagy can function to promote cell survival or cell death under various cellular conditions. Autophagy is also important to engulf damaged ER in the unfolded protein response [6]. The ATG16L1 gene is coding the protein called autophagy related 16 -like 1 . This protein is part of a larger family of proteins that are required for a process called autophagy. Autophagy is involved in the body's inflammatory response and helps the immune system to destroy some types of harmful bacteria and viruses. The effects of variations in the ATG16L1 gene in Crohn's 
disease pathogenesis are unclear. Changes in this gene may affect the autophagy process, allowing worn-out cell parts and harmful bacteria to persist when they would otherwise be destroyed. These cell components and bacteria may trigger an inappropriate immune system response, leading to chronic intestinal inflammation and the digestive problems which are hallmark of CD pathogenesis. Thus, there is a relationship between $\mathrm{AhR}$, apoptosis, response to endoplasmic reticulum stress, autophagy and ATG16L1 [7, 8].

Therefore the aim of this study was to investigate the expression of AhR and ATG16L1 protein in experimental oxazolone-induced colitis in rats and anti-inflammatory action of recombinant antagonist of IL-1 receptors (ARIL-1) and simvastatin.

\section{METHODS}

\section{Animals and Tissue isolation}

Eight-month-old male Wistar rats were purchased from Institute of Molecular Biology and Genetics (National Academy of Science of Ukraine, Kyiv) and kept in a 12-h light/dark cycle with controlled humidity (60-80\%) and temperature $\left(22^{\circ} \pm 1^{\circ} \mathrm{C}\right)$. Food and water were freely available. All animal experiments were performed according to international principles "of the European Convention for the Protection of vertebrate animals used for experimental and other scientific purposes" (Strasbourg, 18.03.1986) and "General ethical principles of animal research" (Ukraine, 2001). Single animals were fasted overnight and sacrificed by cervical dislocation after receiving an overdose of ether for the isolation of gut tissue. Rats were euthanized 6 days after induction of colitis. For macroscopic observation, the colon was dissected from rats. The distal colon was removed, opened longitudinally and the mucosal damage was scored on a $0-10$ scale according to the criteria of Bobin-Dubigeon et al. [9]. After removal of the colon, the tissue was flushed with cold phosphate buffered saline. The colon tissue samples were fixed in in Bouin's solution and embedded in paraffin for histological analysis. Tissues were scored semi-quantitatively from 0 to $5(0$, no changes to 5 , marked transmural inflammation with severe ulceration and loss of intestinal glands) in a blinded fashion according to previously described criteria [10]. For histochemical studies, colon tissue samples were fixed in formalin, and after paraffin embedding $5 \mu \mathrm{m}$ sections were cut and stained with a monoclonal antibody.

Drugs

Simvastatin was obtained from Sigma-Aldrich (St. Louis, MO) and prepared as a $4 \mathrm{mg} / \mathrm{ml}$ stock. Briefly, $4 \mathrm{mg}$ was dissolved in $100 \mu \mathrm{l}$ of ethanol and $150 \mu \mathrm{l}$ of $0.1 \mathrm{~N} \mathrm{NaOH}$, incubated at $50^{\circ} \mathrm{C}$ for $2 \mathrm{~h}$, and then $\mathrm{pH}$ adjusted to 7 and volume corrected to $1 \mathrm{ml}$. It was chemically activated by alkaline hydrolysis before subcutaneous injection. ARIL-1 was kindly provided by Resbio LLC (St. Petersburg, Russia). Substance ARIL-1 consists of 153 amino acids obtained by genetic engineering technology. The substance is lyophilized protein IL-1ra, which produced by a recombinant strain E. coli BL21.

Oxazolone-induced colitis

Oxazolone (4-ethoxymethylene-2-phenyl-2oxazoline-5-one) was obtained from SigmaAldrich (St. Louis, MO). In order to presensitize rats, a $2 \times 2 \mathrm{~cm}$ field of the abdominal skin was shaved, and $200 \mu \mathrm{l}$ of a $3 \%(\mathrm{w} / \mathrm{v})$ solution of oxazolone in $100 \%$ ethanol was applied. 7 days after presensitization intrarectal injection was performed $0.1 \%$ oxazolone in $50 \%$ ethanol (1.5 mg/kg of body weight) under general anesthesia with ketamine, $4 \sim 8 \mathrm{~cm}$ proximal to the anal verge of rats using a catheter $(1 \mathrm{~mm}$ diameter) (Sherwood, St. Louis, MO) [9]. Rats were kept in a head-down position for $30 \mathrm{~s}$ and then returned to their cages. Ethanol (40\%) is used to help haptens go through the intestinal epithelial barrier.

\section{Animal groups}

Rats were divided into four experimental groups: group 1 - control (rectal challenge with $50 \%$ ethanol only); group 2 - rats with 
oxazolone-induced colitis; group 3 - rats given simvastatin $(20 \mathrm{mg} / \mathrm{kg}, 2 \mathrm{ml} / \mathrm{kg}$ in the mixture of ethanol, $\mathrm{H}_{2} \mathrm{O}, \mathrm{NaOH}$ and $\mathrm{HCl}$ for 5 days, intraperitoneally); group 4 - rats given ARIL1 (3 mg/kg, $2 \mathrm{ml} / \mathrm{kg}$ in the phosphate buffer solution (PBS) for 5 days, subcutaneously).

Immunohistochemical staining

Formalin-fixed, paraffin embedded colon sections $(5-7 \mu \mathrm{m})$ placed on coated slides were sequentially deparaffinized and rehydrated using xylene and ethanol, washed in PBS (twice, $5 \mathrm{~min}$ each). After rinsing in $0.1 \mathrm{M}$ PBS, the sections were incubated overnight at $4{ }^{\circ} \mathrm{C}$ with the respective primary antibody (dilution 1:50): Aryl hydrocarbon Receptor (H-211: sc-5579) - a rabbit anti-mouse polyclonal antibody or Atg16 Antibody (C-20: sc-70133) - a goat polyclonal IgG, (Santa Cruz Biotechnology, INC, CA). On the second day, after washing, sections were incubated for $1 \mathrm{~h}$ with a mixture of FITC-conjugated goat anti-rabbit IgG or rabbit anti-goat IgG (Santa Cruz Biotechnology, INC, CA, catalog numbers sc-2012, sc-2777). While protected from direct light exposure, samples were washed three times in PBS and mounted. Fluorescent images were obtained with a fluorescence microscope PrimoStar (ZEISS, Germany) with a computer-assisted video system AxioCam 5c (ZEISS, Germany). Fluorescent signal intensity was quantified using ImageJ software (NIH Image version 1.46). The lamina propria of mucous layer (LAM PR) and tela submucosa (TELA SUBM) colon were studied.

Statitical analysis

Results were statistically treated with Student's t-test using STATISTICA 6.0 (StatSoft Inc. 2001,
USA) and presented as mean \pm SEM. Statistical differences were considered significant if the $\mathrm{P}$ value was $<0.05$.

\section{RESULTS}

Animals treated with oxazolone rapidly developed colitis marked by weight loss and diarrhea peaking by day 2 after oxazolone administration and leading to death of $40 \%$ of the rats by day 4 . Thereafter, surviving animals at days 4-7 after oxazolone administration slowly increased their weight and by days 10-12 the majorities of the rats were free of diarrhea and appeared healthy. In accordance with these observations, histologic examination revealed loss of normal architecture, a mixed cell inflammatory infiltrate, and areas of epithelial erosion. Control rats treated with $50 \%$ ethanol alone did not develop wasting disease and exhibited a healthy appearance. Administrations of simvastatin and ARIL1 resulted in a significant reduction in clinical, macroscopic and microscopic parameters of colitis compared with the vehicle-treated group (Table 1).

The study of serial sections of colon showed that the development of colitis is not accompanied by changes of total number of AhR immunopositive lymphocytes $\left(\mathrm{AhR}^{+}\right)$in lymphoid structures of colon (Fig. 1A, D).

But, the administrations of simvastatin in experimental animals during the development of experimental pathology was accompanied by decrease of $\mathrm{AhR}^{+}$-cells by $38 \%$ (in LAM $\mathrm{PR}, \mathrm{P}<0.05$ ) in proximal colon (Fig. 1B); by $24 \%$ (in TELA SUBM, P <0.05) in distal colon in comparison with vehicle-treated group (Fig.

Table 1. Effect of simvastatin or ARIL-1 on clinical parameters of oxazolone-induced colitis in rats (mean \pm SD).

\begin{tabular}{lccccc|}
\hline Group & $\mathrm{n}$ & Body weight $(\mathrm{g})$ & Macroscopy score & Histology score \\
\hline Control & 10 & $130.3 \pm 14.2$ & $1.00 \pm 0.71$ & $1.00 \pm 0.71$ \\
Oxazolone-induced colitis & 15 & $105.0 \pm 10.9^{*}$ & $6.60 \pm 0.55^{*}$ & $14.00 \pm 1.22^{*}$ \\
Colitis + simvastatin & 15 & $115.2 \pm 11.5^{*}$ & $3.20 \pm 0.43^{*}$ & $5.00 \pm 1.13^{*}$ \\
Colitis + ARIL-1 & 15 & $117.1 \pm 11.3^{*}$ & $3.00 \pm 0.25^{*}$ & $3.00 \pm 0.42^{*}$ \\
\hline
\end{tabular}

$* \mathrm{P}<0.05$, vs. control group. 
1E). The measuring of fluorescence intensity of $\mathrm{AhR}^{+}$-lymphocytes expressing the AhR showed reliable decrease of this parameter in $\mathrm{AhR}^{+}$small lymphocytes by $10 \%$ (in TELA SUBM, $\mathrm{P}<0.05$ ), but the increase in ATG16L1+-lymphoblasts by $24 \%$ (in TELA SUBM, P <0.05) in proximal colon.

The administrations of ARIL-1 to experimental animals during the development of experimental pathology was accompanied by the decrease of $\mathrm{AhR}^{+}$-cells by $34 \%$ (in TELA SUBM, $\mathrm{P}<0.05$ ) in proximal colon (Fig. 1C); by twice (in TELA SUBM, $\mathrm{P}<0.05$ ) in distal colon in comparison with vehicle-treated group (Fig. 1F).

The study of serial sections of colon showed that the development of colitis is accompanied by changes of total number of ATG16L1 immunopositive lymphocytes $\left(\mathrm{ATG} 16 \mathrm{~L}^{+}{ }^{+}\right.$) in lymphoid structures of colon - increase of ATG16L $1^{+}$-cells by $30 \%$ (in TELA SUBM, $\mathrm{P}<0.05$ ) in proximal colon (Fig. 2A). The measuring of fluorescence intensity of ATG16L $1^{+}$lymphocytes expressing the concentration of ATG16L1 protein in immunopositive cells showed reliable increase of this parameter in
ATG16L $1^{+}$-small lymphocytes by $8 \%$ (in TELA SUBM, P <0.05), in ATG16L1 ${ }^{+}$-medium lymphocytes by $4 \%$ (in TELA SUBM, $\mathrm{P}<0.05$ ), but the decrease in ATG16L $1^{+}$-lymphoblasts by $9 \%$ (in TELA SUBM, $\mathrm{P}<0.05$ ) in proximal colon. In distal colon we have found increase of this parameter in ATG16 $1^{+}$-lymphoblasts by $11 \%$ (in LAM PR, $\mathrm{P}<0.05$ ) in comparison with control.

The administrations of simvastatin in experimental animals during the development of experimental pathology was accompanied by decrease of ATG16L $1^{+}$-cells by twice (in LAM $\mathrm{PR}, \mathrm{P}<0.05$ ) and by $44 \%$ (in TELA SUBM, $\mathrm{P}<0.05)$ in proximal colon in comparison with vehicle-treated group (Fig. 2B). The measuring of fluorescence intensity of ATG16L $1^{+}$. lymphocytes showed decrease of this parameter in ATG16L1 ${ }^{+}$- small lymphocytes by $16 \%$ (in TELA SUBM, $\mathrm{P}<0.05$ ) in proximal colon; decrease in ATG16L1 ${ }^{+}$-small lymphocytes by $11 \%$ (in LAM PR, $\mathrm{P}<0.05$ ) in distal colon.

The administrations of ARIL-1 to experimental animals during the development of experimental pathology was accompanied by the decrease of ATG16L1 ${ }^{+}$-cells by $43 \%$ (in LAM
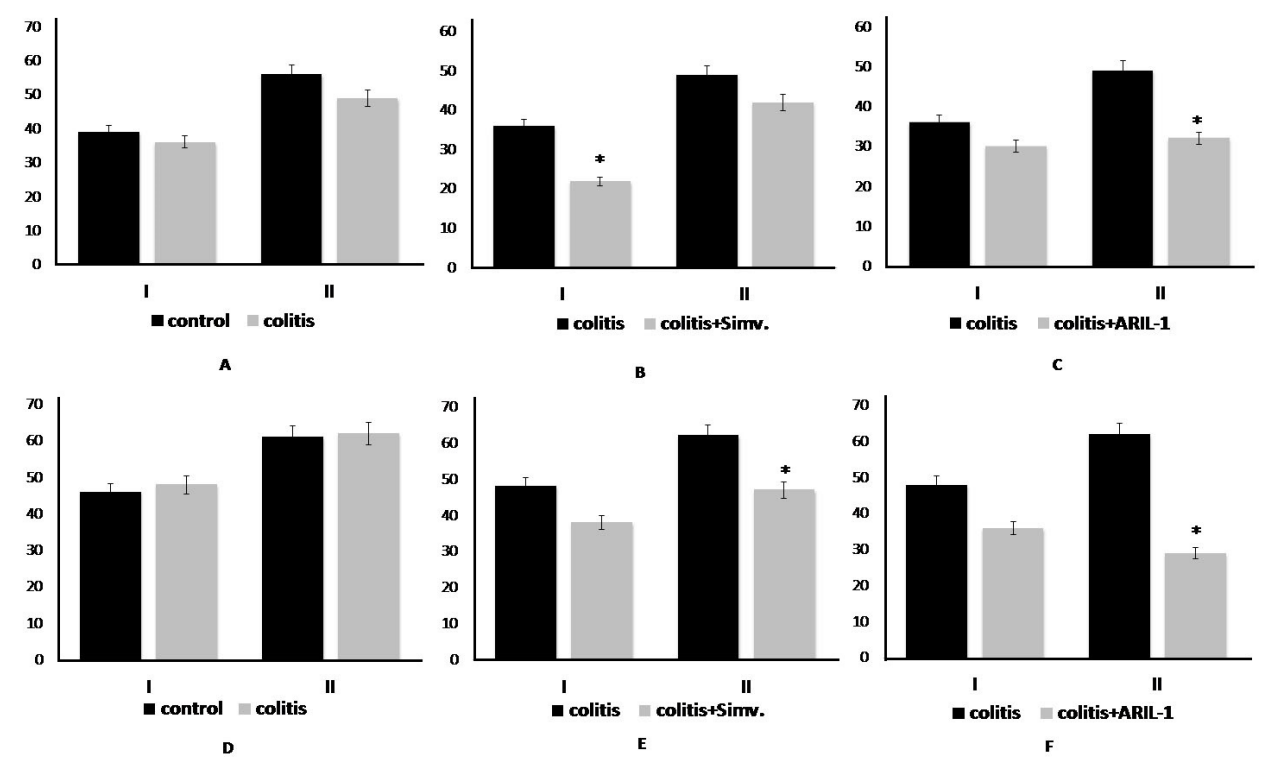

Fig. 1. The number (on $1 \mathrm{~mm}^{2}$ ) of $\mathrm{AhR}^{+}$-cells in proximal colon during the development of colitis (A) and after administration of simvastatin (B) or ARIL-1 (C) to experimental animals during the development of colitis; distal colon during the development of colitis (D) and after administration of simvastatin (E) or ARIL-1 (F) to experimental animals during the development of colitis: I - lamina propria of mucous layer; II - tela submucosa. $* \mathrm{P}<0.05$ (paired two-group t-test, compared with control or colitis) 
PR, $\mathrm{P}<0.05$ ) and by $44 \%$ (in TELA SUBM, $\mathrm{P}$ $<0.05$ ) in proximal colon (Fig. 2C); by $39 \%$ (in TELA SUBM, $\mathrm{P}<0.05$ ) in distal colon in comparison with vehicle-treated group (Fig. 2F). The measuring of fluorescence intensity of ATG16L $1^{+}$-lymphocytes showed decrease of this parameter in ATG16 $\mathrm{L}^{+}$-small lymphocytes by $13 \%$ (in TELA SUBM, $\mathrm{P}<0.05$ ) in proximal colon; decrease in ATG16L1 ${ }^{+}$- lymphoblasts by $12 \%$ (in LAM PR, P $<0.05$ ) in distal colon.

\section{DISCUSSION}

We found that the development of colitis is not accompanied by changes of total number of $\mathrm{AhR}^{+}$in lymphoid structures of colon, but these results do not corroborate recent studies Furumatsu et al. [11], because they have described the development of colitis during DSS administration is associated with increased the expression levels of AhR and CYP1A1 mRNA in the colon epithelium. In addition, oral administration of $\beta$-naphthoflavone $(\beta N F)$, a non-toxic agonist of AhR, suppressed the pathogenesis of DSS-induced colitis. $\beta \mathrm{NF}$ also attenuated
DSS-induced colitis. In cell culture experiments, downregulation of AhR in human colon carcinoma SW480 cells enhanced the inflammatory responses evoked by lipopolysaccharide (LPS), and furthermore, AhR activation attenuated LPS-induced inflammatory responses, suggesting that AhR expressing intestinal epithelial cells are involved in the prevention of colitis. Analysis of AhR in the human gut reveals that intestinal $\mathrm{T}$ cells and natural killer cells isolated from Crohn's disease patients express low levels of AhR and respond to AhR ligands by downregulating inflammatory cytokines and upregulating IL-22 [2].

Functional ATG16L1 is crucial for the induction of autophagy. Atg5-Atg12 protein conjugates interact with Atg16L1 to form a high molecular weight protein complex essential for the elongation of the autophagosomal membrane. Caspase 3 activation in the presence of a common risk allele leads to accelerated degradation of ATG16L1, placing cellular stress, apoptotic stimuli and impaired autophagy in a unified pathway that predisposes to Crohn's disease [12].
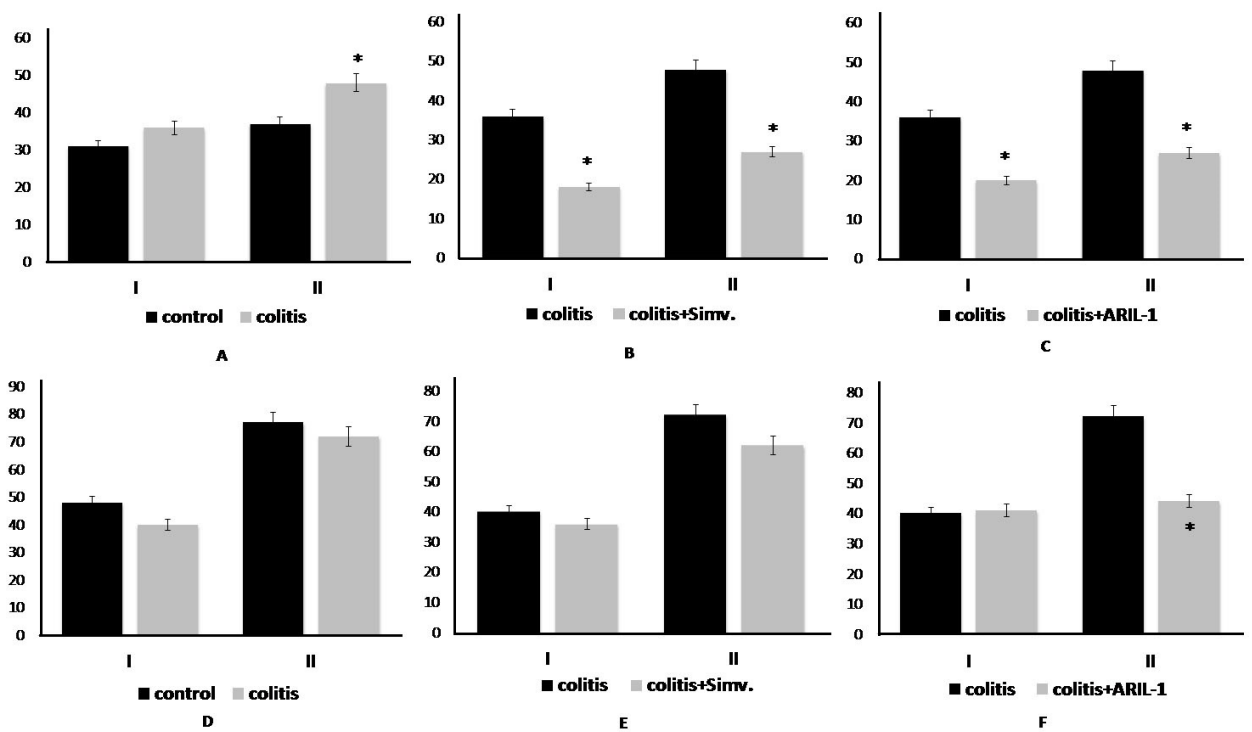

Fig. 2. The number (on $1 \mathrm{~mm}^{2}$ ) of ATG16L1 ${ }^{+}$-cells in proximal colon during the development of colitis (A) and after administration of simvastatin (B) or ARIL-1 (C) to experimental animals during the development of colitis; in distal colon during the development of colitis (D) and after administration of simvastatin (E) or ARIL-1 (F) to experimental animals during the development of colitis: I - lamina propria of mucous layer; II - tela submucosa. $* \mathrm{P}<0.05$ (paired two-group t-test, compared with control or colitis) 
Saitoh et al. [13] demonstrated that Atg16L1-deficient chimeric mice administered 5\% DSS for 7 days exhibited a marked exacerbation of colitis with reduced survival. Mice lacking Atg16L1 in haematopoietic cells are highly susceptible to dextran sulphate sodium-induced acute colitis, which is alleviated by injection of anti-IL-1 $\beta$ and IL-18 antibodies, indicating the importance of Atg16L1 in the suppression of intestinal inflammation. Atg16L $1^{\mathrm{HM}}$ mice exhibited increased susceptibility to DSS colitis, which could be abrogated by antibiotic treatment, or administration of anti-TNF or anti-IFN $\gamma$ antibodies [14].

Our results about the ability of simvastatin to affect proinflammatory signaling in the gut are indirectly confirmed by other authors. Simvastatin has been shown to inhibit acute as well as chronic inflammatory responses in a cholesterol-independent manner by interfering with endothelial adhesion and leukocyte migration to sites of inflammation [15]. In rats with normal blood cholesterol levels, simvastatin was found to ameliorate immunopathology in an acute TNBS colitis model by blocking neutrophil accumulation in the small intestine and lowering serum TNF- $\alpha$ level [16]. Administration of simvastatin significantly reduced the severity of DSS-induced murine colitis as assessed by body weight, colon length and histology in a dose-dependent manner [17].

Administration of recombinant IL-1Ra prevents mucosal inflammation and necrosis in a rabbit model of dextran-induced colitis [18]. Conversely, neutralization of endogenous IL$1 \mathrm{Ra}$ increases the severity of intestinal inflammation, indicating that endogenous IL-1 Ra plays an anti-inflammatory role. The importance of IL-1 and IL-1Ra in the pathogenesis of IBD has been corroborated by the association between carriage of IL-1RN allele 2, low production of IL-1Ra and severity of disease in UC patients [19]. Our data demonstrate ability of ARIL-1 to influence the level of expression of pattern recognition receptors and show therefore potential in the correction of immune disorders in
IBD. Characteristically, ARIL-1 operates as pure antagonist by blocking communication between the molecules of IL-1 (IL- $1-\alpha$, IL-1- $\beta$ ) and IL-1 receptor that allows providing effective control for the whole IL-1 system in the body.

\section{CONCLUSION}

Development of colitis was accompanied by changes of total number of ATG16L $1^{+}$lymphocytes in proximal part of the colon, but not accompanied with the change of amount of $\mathrm{AhR}^{+}$-lymphocytes, and change the density of AhR and ATG16L1 in immunopositive cells.

Administration of anti-inflammatory compounds simvastatin and antagonist of IL-1 receptors during the development of experimental colitis results in the decrease of total number of $\mathrm{AhR}^{+}$and ATG16L1+-lymphocytes in the colon and was accompanied by changes in their density on lymphocytes.

\section{CONFLICT OF INTEREST STATEMENT}

The authors declare that the research was conducted in the absence of any commercial or financial relationships that could be construed as a potential conflict of interest.

\section{ACKNOWLEDGEMENTS}

The authors thank Inna Topol and Anna Degen for excellent technical assistance.

\section{А.С. Жеребятьев, А.М. Камышный}

\section{ЭКСПРЕССИЯ АРИЛ-ГИДРОКАРБОНОВЫХ РЕЦЕПТОРОВ И БЕЛКА АТG16L1 ПРИ ЭКСПЕРИМЕНТАЛЬНОМ ОКСАЗОЛОН- ИНДУЦИРОВАННОМ КОЛИТЕ У КРЫС}

Исследована экспрессия арил-гидрокарбоновых рецепторов (AhR) и белка ATG16L1 лимфоцитами толстого кишечника при экспериментальном колите у крыс и противовоспалительный эффект рекомбинантного антагониста рецепторов IL-1 (АРИЛ-1) и симвастатина. Иммунопозитивные лимфоциты были определены методом непрямой иммунофлюоресценции с использованием моноклональных антител крысы. Установлено, что развитие 
колита сопровождалось увеличением общего количества ATG16L $1^{+}$-лимфоцитов (на $30 \%, \mathrm{P}<0,05$ ) в лимфоидных структурах толстой кишки. Однако количество $\mathrm{AhR}^{+}$лимфоцитов не изменялось. В то же время увеличилась концентрация белка ATG16L1 (на 4-11\%, P <0,05) в иммунопозитивных клетках. Ведение симвастатина и АРИЛ-1 во время развития экспериментальной патологии сопровождается снижением количества $\mathrm{AhR}^{+}$(на 24-38\%, $\mathrm{P}<0,05)$ и ATG16L1 ${ }^{+}$-лимфоцитов (на $43 \%$ - в 2 раза, $\mathrm{P}$ $<0,05)$ в толстой кишке.

Ключевые слова: колит; рекомбинантный антагонист рецепторов интерлейкина-1 (АРИЛ-1); симвастатин; арил-гидрокарбоновый рецептор; белок, связанный с аутофагией $16 \mathrm{~L} 1$.

Запорожский государственный медицинский университет

\section{О.С. Жеребятьєв, О.М. Камишний}

\section{ЕКСПРЕСІЯ АРИЛ-ГІДРОКАРБОНОВИХ РЕЦЕПТОРІВ І БІЛКА АТG16L1 ПРИ ЕКСПЕРИМЕНТАЛЬНОМУ ОКСАЗОЛОН- ІНДУКОВАНОМУ КОЛІТІ У ЩУРІВ}

Досліджена експресія арил-гідрокарбонових рецепторів $(\mathrm{AhR})$ i білка ATG16L1 лімфоцитами товстого кишечника при експериментальному коліті у щурів і протизапальний ефект рекомбінантного антагоніста рецепторів IL-1 (АРІЛ-1) і симвастатину. Імунопозитивні лімфоцити були визначені методом непрямої імунофлюоресценції 3 використанням моноклональних антитіл щура. Встановлено, що розвиток коліту супроводжувався збільшенням загальної кількості ATG16L1+-лімфоцитів (на $30 \%$, $\mathrm{P}<0,05)$ у лімфоїдних структурах товстої кишки. Однак кількість $\mathrm{AhR}^{+}$-лімфоцитів не змінилась. Водночас збільшилась концентрація білка ATG16L1 (на 4-11\%, $\mathrm{P}<0,05)$ в імунопозитивних клітинах. Введення симвастатину й АРІЛ-1 під час розвитку експериментальної патології супроводжувалося зменшенням кількості $\mathrm{AhR}^{+}$ (на $24-38 \%, \mathrm{P}<0,05$ ) і ATG16L1 ${ }^{+}$-лімфоцитів (на 43\% - в 2 рази, $\mathrm{P}<0,05)$ в товстій кишці.

Ключові слова: коліт; рекомбінантний антагоніст рецепторів інтерлейкіну-1 (АРІЛ-1); симвастатин; арил-гідрокарбоновий рецептор; білок, пов'язаний з аутофагією $16 \mathrm{~L} 1$.

Запорізький державний медичний університет

\section{REFERENCES}

1. Kaser A, Zeissig S, Blumberg RS. Inflammatory bowel disease. Annu Rev Immunol.2010;28:573-621.

2. Monteleone I, MacDonald TT, Pallone F, Monteleone G. The aryl hydrocarbon receptor in inflammatory bowel disease: linking the environment to disease pathogenesis. Curr Opin Gastroenterol. 2012 Jul;28(4):310-3.

3. Ray SS, Swanson HI. Dioxin-induced immortalization of normal human keratinocytes and silencing of p53 and p16INK4a. J Biol Chem. 2004 Jun 25;279(26):27187-93.

4. Marlowe JL, Fan Y, Chang X, Peng L, Knudsen ES, Xia $\mathrm{Y}$, et al. The aryl hydrocarbon receptor binds to $\mathrm{E} 2 \mathrm{~F} 1$ and inhibits E2F1-induced apoptosis. Mol Biol Cell. 2008 Aug;19(8):3263-71.

5. Shimada T, Hiramatsu N, Hayakawa K, Takahashi S, Kasai A, Tagawa Y, et al. Dual suppression of adipogenesis by cigarette smoke through activation of the aryl hydrocarbon receptor and induction of endoplasmic reticulum stress. Am J Physiol Endocrinol Metab. 2009 Apr;296(4):E721-30.

6. Høyer-Hansen M, Jäättelä M. Connecting endoplasmic reticulum stress to autophagy by unfolded protein response and calcium. Cell Death Differ. 2007 Sep;14(9):1576-82.

7. Hampe J, Franke A, Rosenstiel P, Till A, Teuber M, Huse K, et al. A genome-wide association scan of nonsynonymous SNPs identifies a susceptibility variant for Crohn disease in ATG16L1. Nat Genet. 2007 Feb;39(2):207-11.

8. Mizushima N, Kuma A, Kobayashi Y, Yamamoto A, Matsubae M, Takao T, et al. Mouse Apg16L, a novel WD-repeat protein, targets to the autophagic isolation membrane with the Apg12-Apg5 conjugate. J Cell Sci. 2003 May 1;116(Pt 9):1679-88.

9. Bobin-Dubigeon C, Collin X, Grimaud N, Robert JM, Le Baut G, Petit JY. Effects of tumour necrosis factor-alpha synthesis inhibitors on rat trinitrobenzene sulphonic acid-induced chronic colitis. Eur J Pharmacol. 2001 Nov 9;431(1):103-10.

10. Boirivant M, Fuss IJ, Chu A, Strober W. Oxazolone colitis: A murine model of T helper cell type 2 colitis treatable with antibodies to interleukin 4. J Exp Med. 1998 Nov 16;188(10):1929-39.

11. Furumatsu K, Nishiumi S, Kawano Y, Ooi M, Yoshie T, Shiomi Y, et al. A role of the aryl hydrocarbon receptor in attenuation of colitis. Dig Dis Sci. 2011 Sep;56(9):2532-44.

12. Murthy A, Li Y, Peng I, Reichelt M, Katakam AK, Noubade R, et al. A Crohn's disease variant in Atg1611 enhances its degradation by caspase 3. Nature. $2014 \mathrm{Feb}$ 27;506(7489):456-62.

13. Saitoh T, Fujita N, Jang MH, Uematsu S, Yang BG, Satoh $\mathrm{T}$, et al. Loss of the autophagy protein Atg16L1 enhances endotoxin-induced IL-1beta production. Nature. 2008 Nov 13;456(7219):264-8.

14. Cadwell K, Patel KK, Maloney NS, Liu TC, Ng AC, Storer CE, et al. Virus-plus-susceptibility gene interaction determines Crohn's disease gene Atg16L1 phenotypes in intestine. Cell. 2010 Jun 25;141(7):1135-45.

15. Maher BM, Dhonnchu TN, Burke JP, Soo A, Wood AE, Watson RW. Statins alter neutrophil migration by modulating cellular Rho activity--a potential mechanism for statins-mediated pleotropic effects? J Leukoc Biol. $2009 \mathrm{Jan} ; 85(1): 186-93$.

16. Jahovic N, Gedik N, Ercan F, Sirvanci S, Yüksel M, Sener $\mathrm{G}$, et al. Effects of statins on experimental colitis in normocholesterolemic rats. Scand J Gastroenterol. 2006 Aug;41(8):954-62. 
17. Lee JY, Kim JS, Kim JM, Kim N, Jung HC, Song IS. Simvastatin inhibits NF-kappaB signaling in intestinal epithelial cells and ameliorates acute murine colitis. Int Immunopharmacol. 2007 Feb;7(2):241-8.

18. Youngman KR, Simon PL, West GA, Cominelli F, Rachmilewitz D, Klein JS, et al. Localization of intestinal interleukin 1 activity and protein and gene expression to lamina propria cells. Gastroenterology. 1993 Mar;104(3):749-58.

19. Tountas NA, Casini-Raggi V, Yang H, Di Giovine FS, Vecchi M, Kam L, et al. Functional and ethnic association of allele 2 of the interleukin-1 receptor antagonist gene in ulcerative colitis. Gastroenterology. 1999 Oct;117(4):806-13.

Received 08.11.2014 